\title{
Farm seeker needs versus farm owner offers: A comparison and analysis in the U.S. Midwest and Plains
}

\author{
Julia C. D. Valliant a * \\ Indiana University
}

Kathryn Z. Ruhf b

Land For Good

\author{
Stephanie L. Dickinson, ${ }^{c}$ Yijia Zhang, ${ }^{c}$ Lilian Golzarri-Arroyo, ${ }^{c}$ and James R. Farmer a, d \\ Indiana University
}

Submitted March 4, 2019 / Revised May 28 and July 21, 2019 / Accepted July 21, 2019 / Published online February 6, 2020

Citation: Valliant, J. C. D., Ruhf, K. Z., Dickinson, S. L., Zhang, Y., Golzarri-Arroyo, L., \& Farmer, J. R. (2020). Farm seeker needs versus farm owner offers: A comparison and analysis in the U.S. Midwest and Plains. Journal of Agriculture, Food Systems, and Community Development, 9(2), 141-157. https://doi.org/10.5304/jafscd.2020.092.006

Copyright (C) 2020 by the Authors. Published by the Lyson Center for Civic Agriculture and Food Systems. Open access under CC-BY license.

\begin{abstract}
Land access for new farmers and ranchers includes transfers from owners without family successors. We compare how farm seekers' needs align with the offerings of farm owners whose farm assets
\end{abstract}

a * Corresponding author: Julia C. D. Valliant, Sustainable Food Systems Science, The Ostrom Workshop, Indiana University; 515 North Park Avenue; Bloomington, Indiana 47408 USA; +1-812-856-5029; jdv@indiana.edu

b Land For Good; P.O. Box 625; Keene, New Hampshire 03431 USA; +1-603-357-1600; kathy@landforgood.org

${ }^{c}$ Department of Epidemiology and Biostatistics, School of Public Health, Indiana University; 1025 East Seventh Street, Room C036; Bloomington, IN 47408 USA; sd3@indiana.edu; yz201@iu.edu; lgolzarr@indiana.edu

d School of Public and Environmental Affairs, Indiana University; 515 North Park Avenue; Bloomington, IN 47408 USA; +1-812-856-0969; jafarmer@indiana.edu may transfer out of family in the 12-state North Central Region as defined by the U.S. Department of Agriculture. ${ }^{1}$ In Phase 1, managers of farm link services, which connect farm owners without a successor in their family to farm seekers, estimated the patterns demonstrated by their program's seeker and owner participants through a questionnaire. In Phase 2, managers of these and select other agricultural and rural programs circulated to

\section{Funding Disclosure}

This material is based upon work that is supported by the National Institute of Food and Agriculture, U.S. Department of Agriculture, under award number 2016-38640-25381, through the North Central Region SARE program under project number LNC16-377. USDA is an equal opportunity employer and service provider. Any opinions, findings, conclusions, or recommendations expressed in this publication are those of the authors and do not necessarily reflect the view of the U.S. Department of Agriculture.

1 The North Central Region includes the states of Illinois, Indiana, Iowa, Kansas, Michigan, Minnesota, Missouri, Nebraska, North Dakota, Ohio, South Dakota, and Wisconsin. 
their networks an online survey whose respondents included 178 farm seekers and 183 farm owners whose assets may transfer out of family. Findings denote similarities and barriers between the two groups. The biggest difference was that few owners offered an on-farm residence, which was a top need of seekers. In terms of similarities, the survey found no statistical differences in the groups' respective locations on a rural-urban continuum, nor in land parcel sizes sought and offered. Half of farm link service providers concurred, observing a match between seeker and owner land needs. However, the other half of service providers reported wide differences, observing two patterns. First, incoming farmers preparing for commodity row crop, hay and fodder, and beef production are well-matched by owners with like type farms to offer, although new entrants often seek bigger parcels than owners offer. Second, seekers preparing for specialty crop, dairy, and hog or poultry (outdoor and indoor) production far exceed the number of owners who offer the infrastructure and scale for these production systems, particularly for parcels under 40 acres. $^{2}$ Results suggest opportunities for research and intervention to target barriers and areas of alignment between owner and seeker needs, especially for affordable on-farm housing for new farm operators.

\section{Keywords}

Beginning Farmers and Ranchers, Farm Transfer, Farm Succession, Farm Link, Rural Housing, Rural Development, Small and Medium Farms

\section{Introduction and Literature Review}

Beginning farmers and ranchers who seek to own or lease a farm contend with many obstacles to starting and succeeding in agriculture. Some obstacles are ingrained in patterns of farm and ranch transfer from one owner to the next. (Hereafter, we use "farmers" and "farms" to encompass ranchers and ranches as well.) Farm transfers cycle continuously across the land, sometimes within a family and other times between unrelated parties, which is the focus of this study. It is estimated that $25 \%$ of farm transfers underway at any time are between non-relatives (USDA NASS, 2015), such that the majority of farmland is actually acquired from a non-relative (Ahearn, 2013). Agreement is clear that farm transfers are generally a difficult turning point for both entering and exiting parties. This paper queries one aspect of that difficulty by examining how well farm owner offers appear to align with farm seeker needs, across a 12-state Midwestern and Central Plains region.

Food system innovation and agricultural productivity can benefit from improved farm transfers (Leonard, B., Kinsella, O'Donoghue, Farrell, \& Mahon, 2017; Ruhf, 2013). Agricultural programs and policies, known as farm link programs, for over three decades have implemented a range of strategies to assist farm families in transferring their land to farmers of the next generation (Valliant, Ruhf, Gibson, Brooks, \& Farmer, 2019). A number of terms refer to these next-generation farm seekers and subgroups among them, including beginning farmers (USDA ERS, 2019), young farmers (e.g., Ackoff, Bahrenburg, \& Shute, 2017), nextgeneration farmers (e.g., Harper, 2015), firstgeneration farmers and multigenerational farmers (e.g., Inwood, 2013). We use "farm seeker" to refer to a farmer who is not yet established and is seeking a farming opportunity. Encouraging seekers' prospects for entering and succeeding in agriculture is an impetus for programs that assist with farm transfers in some capacity, because agricultural innovation and investment in the farm business are greater on farms where a successor or transferee is identified and preparing to assume leadership (Chiswell, 2014; Inwood \& Sharp, 2012; Lobley \& Baker, 2012; Lobley, Baker, \& Whitehead, 2010). In addition, entering farmers make an outsized contribution to the categories of renewable agriculture that are tracked by the U.S. Census of Agriculture. For example, beginning farmers represent about $16 \%$ of operators (USDA NASS, $2012 \mathrm{~b})$, but are responsible for $26 \%$ of certified organic sales in the U.S. and $22 \%$ of direct-toconsumer sales (USDA NASS, 2014). These food system and agriculture outcomes motivate initiatives to help new farming entrants begin and succeed.

21 acre $=0.4$ hectare 
A second impetus for farm link services is the recognition that entering agriculture and retiring from agriculture make up two sides of the same coin. As Parsons and his colleagues have observed, "Barriers to both farm entry and farm exit are in play. If older farmers can't easily exit, their land can't become available to entering farmers" (2010, p. 10). Supporting farmers in preparing for farm transfer is one way of helping new farmers, at the other end of the life course, to gain access to farmland, which surveys of new entrants find to be a widespread difficulty (Ackoff et al., 2017; Freedgood \& Dempsey, 2014; Paine \& Sullivan, 2014). There are many new farmers in the U.S.; one estimate suggests there are 70,000 every year (Katchova \& Ahearn, 2017). For context, this is the same number of farms in the entire state of Wisconsin (USDA NASS, 2012a), the ninth top producing state in the nation (USDA ERS, 2017). Since most beginning farmers do not stand to inherit land (Katchova \& Ahearn, 2016), accessing a farming opportunity, ideally with adequate tenure security and on-farm housing, is of utmost priority for many entrants.

Correspondingly, because many farm owners have no family successor, they are looking outside the family for the farm's next operator and/or owner. Given this mutual need to make connections beyond family (Grubbström \& Eriksson, 2018), some services assist with farm transfers by aiming to "link" or "match" owners and seekers with transfer partners from beyond their personal networks. To assist parties on both ends of the transfer spectrum - farm owners without a family successor and farmers seeking an opportunityfarm link programs aim to connect unrelated farmers to kindle a potential transfer relationship between them. Recent research highlights that deeper understanding is needed about the effectiveness and best practices of the various linking programs (Carolan, 2018; Freedgood \& Dempsey, 2014; Hamilton, 2010; Horst \& Gwin, 2018; Parsons et al., 2010; Schilling, Esseks, Duke, Gottlieb, \& Lynch, 2015).

One critique of services to link or match farmers provides the motivation for this study. Fraas (2015) and others argue that linking services are based on an overly simplistic premise that there is a fit to be found between exiting and entering farmers, when actually the structural needs of the two groups are "incongruent" (Hersey \& Adams, 2017, p. 94). Types of incongruity observed to be barriers include that new entrants are likely to seek smaller acreages for producing specialty crops and/or raising and finishing animals outdoors, but that outgoing farmers are likely to offer broadacre, commodity crop farms; thus the farm sizes sought and offered are unlikely to match. Another observed incongruity is that seekers wish to farm close to metropolitan markets and amenities, while owners' farms tend to be too rural for those seekers. In short, there appears to be a mismatch between the needs of farm seekers and the offers of farm owners, such that some analysts have asserted that farm linking services are not very effective (Hersey \& Adams, 2017; Ingram \& Kirwan, 2011). This paper queries the assertion of a mismatch, with a quantitative comparison of what seekers are looking for to what owners offer. We examine the following research questions, with other relevant characteristics of farm seekers and farm owners whose farm assets may transfer out of family:

1. Land: Do seekers want different acreages than owners offer?

2. Geography: Are owners located in places more rural than those that seekers desire?

3. Home: Do seekers want an on-farm residence, and do owners have one to offer?

\section{Applied Research Methods}

\section{Phase 1: Farm link service providers' observations of seeker and owner program participants}

This study focused on services, seekers, and owners in the North Central Region (NCR) of the U.S., which includes the 12 states of the Midwest and Central Plains (Illinois, Indiana, Iowa, Kansas, Michigan, Minnesota, Missouri, Nebraska, North Dakota, Ohio, South Dakota, and Wisconsin). The purpose was to gather best practice recommendations from the managers of the active and closed farm link services in the region and to learn about service gaps and opportunities from farm owners and seekers themselves (Farmer \& Valliant, 2016; 
Valliant et al., 2019). A purposeful strategy aimed to select every farm link service that operates in these states, or that did in the past, in order to learn from information-rich cases that are active as well as those that have discontinued services (Patton, 2002). Thirty-eight programs met one or both of two conditions for inclusion. The first was that the program be listed as a farm listing or linking service in the NCR by a major web resource as of October 2016. These sites were the Center for Rural Affairs "Linking Farmers with Land" page ${ }^{3}$ and the National Young Farmers Coalition Midwest Regional Listings. ${ }^{4}$ The second condition was that the program appear in a search for the term "transfer" in reports of projects funded by North Central Region-Sustainable Agriculture Research and Education (NCR-SARE), a program of the U.S. Department of Agriculture National Institute of Food and Agriculture (USDA-NIFA-SARE, 2018). In January 2017, managers of the 38 programs received an email invitation to an online questionnaire about their programs via the secure survey service Qualtrics. ${ }^{5}$ Between then and March 2017, nonrespondents received up to four emailed and/or phoned reminders. Quantitative data from the questionnaire did not undergo statistical analysis due to the low sample size. We instead undertook analysis using Microsoft Excel in the form of tally, proportion, median and mean values in which respondents approximated and compared the prevalence of characteristics among their seeker and owner participants. We take two approaches to analyzing these responses. One approach uses the program as the unit of analysis. The second incorporates the numbers of seekers and owners who participate in the programs. In both cases, the analysis weights service provider observations of prevalence by assigning a value of zero to the response "none of them"; one to "less than half of them"; two to "more than half of them"; and three to "nearly all of them." The second approach then factors in the number of program participants to depict prevalence across seekers and owners who participate in the NCR farm link services.

\section{Phase 2: Online survey of farm owners and farm seekers}

Farm owners and farm seekers who responded to an online survey formed an availability, or convenience, sample (Schutt, 2006). The survey targeted "farm/ranch owners and farm/ranch seekers in the Plains and Midwest states," and was distributed by programs that focus on agriculture and/or rural communities across the NCR. Between March and June 2017, the 22 programs from Phase 1 that were still active and 10 other programs were invited to send the survey to their networks. The 10 additional programs were purposefully selected to represent states in the NCR that have no farm link services, to attempt to learn from seekers and owners in these states. Of these 32 programs, 26 confirmed having sent the survey on to their networks (17 farm link programs and nine others). Programs distributed the survey via social media, electronic newsletter, and/or direct email. The survey was closed to responses on June 17, 2017.

Data were organized and analyzed using Statistical Analysis Software (SAS) 9.4 (SAS Institute Inc., Raleigh, NC). The Pearson Chi-square test was used to compare the characteristics between the seekers and owners. The analysis involved creating the following variables:

- Residence on a rural-urban continuum according to Rural-Urban Commuting Area (RUCA) codes. (USDA ERS, 2016). Since RUCA values are assigned to census tracts, we used the most recent zip code approximations (University of North Dakota Center for Rural Health, 2014), and categorization $\mathrm{C}$ to achieve two output levels, and categorization $4 \mathrm{E}$ to achieve four output levels (University of Washington Rural Health Research Center, 2005).

- Age: Continuous data were grouped into four categories: 18-29, 30-49, 50-69, 7085.

- Bachelor's degree: We grouped five response options on educational attainment

3 https://www.cfra.org/resources/beginning farmer/linking programs

4 https://www.youngfarmers.org/land-and-jobs/\#Midwest

5 https://www.qualtrics.com 
into two levels to ensure an ample sample size for comparison.

- Couple archetypes: Respondents indicated employment category for themselves and their spouses using USDA Agricultural Resource Management Survey (ARMS) categories ("At which occupation do you/ spouse spend the majority of your work time?") (USDA NASS, 2016). We grouped these responses to depict their occupational status as a couple: both spouses farm, one spouse farms, neither spouse farms, single farmer, and single non-farmer.

\section{Results}

\section{Phase 1: Farm Link Service Provider Observations of Seeker and Owner Participants}

Of the 38 programs that received the online questionnaire, 24 managers filled out one or more paired items about their seeker and owner participants, a response rate of $63 \%$ to these items. Respondents spent a median time of 24 minutes filling out the questionnaire. Compared to nonrespondents, the respondents' programs are more current and directly focus on farm transfers. For example, every respondent program was listed on active websites, whereas all the nonrespondents represented closed programs. Nonrespondents also shared only an ancillary focus on farm transfers, according to our correspondence with the original program managers, their successors, and/or the projects' final reports in the SARE database. According to the survey responses, these 24 programs serve a total of 6,100 owners and seekers, reflecting 3,800 seekers and 2,300 owners.

Respondents represented five projects funded by NCR SARE (US $\$ 490,000$ invested) and eight by the USDA Beginning Farmer and Rancher Development Program (US $\$ 2.8$ million invested, including leads and subcontractors).

\section{Acreage}

Service providers are evenly split as to whether they observe differences between the farm sizes that seekers desire and the sizes of farms that owners offer. While $45 \%$ of programs report no differences, $55 \%$ do observe differences between what their seekers want and what their owners have. Six of the eleven programs $(55 \%)$ that observe differences find that many seekers need smaller tracts than many owners offer. Two other programs report a mixed pattern. The remaining three programs find that many seekers need larger tracts than owners offer. All three programs in this last group primarily serve farmers preparing for commodity crop production. Turning to the amounts of land service providers observe being sought and offered, a caveat to these numbers is that they reflect the variation among the programs, which reflect differences of scale, place, and product mix; this set of programs assists farms at all scales of production, from very small to very large. Together, they report that seeker interest in the smallest and largest tracts (less than 40 and 500+ acres) is greater than owner offerings, while owners offer more land in the 100-499 acre range than seekers need. Seekers and owners are well-matched in the 40-99 acre range, which programs report as the category most frequently both sought and offered.

When we factor in the number of seekers and owners who participate in the programs, which also condenses information from a range of program models and settings, programs report a similar divergent pattern. Seeker demand exceeds supply of the smallest (less than 40) and some of the largest acreages (100-299 and 500-999). Some of these differences are very large (Table 1). Service providers report seeing six to seven times more seekers looking for tracts under 40 acres than owners make available. In the 500-999 acre range, service providers see 100 times more seekers looking for this size range than owners make available. This approach agrees with the first approach, that demand and supply are well-matched in the 40-99 acre range whereas owners actually offer more than is sought in the 300-499 and 1,000+ acre ranges.

\section{Agricultural Products}

Twenty of the 21 programs that responded to these items observe differences between what their owner participants produce and what seekers aim to produce. The one program that observes no differences serves commodity producers. We 
Table 1. Phase 1 Comparison of Seeker Needs and Owner Offers, Weighted by the Prevalence of Interest Farm Link Service Providers Observe among Their Participants (in Order of Descending Seeker Interest)

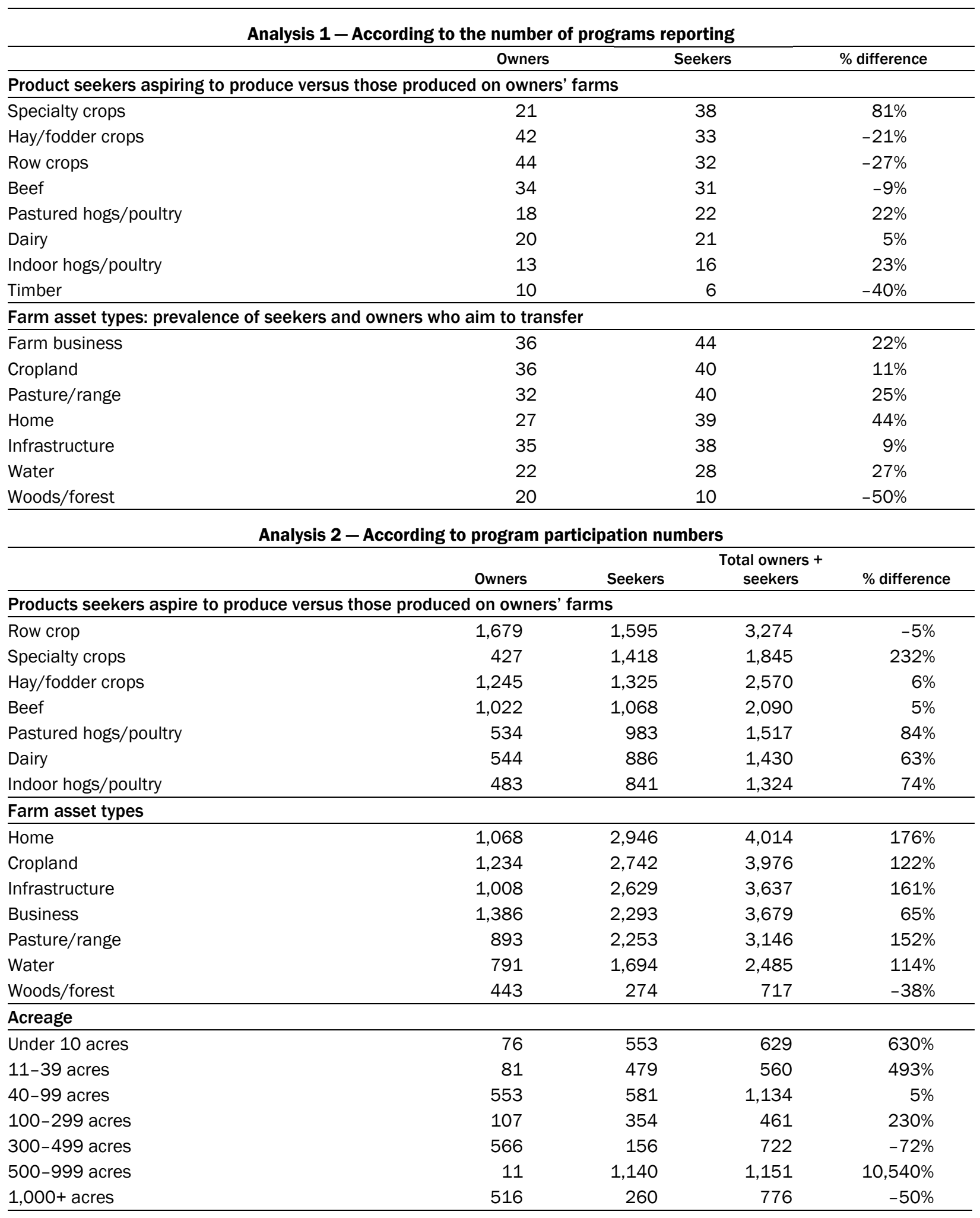

1 acre $=0.4$ hectare 
analyze the reported differences in two ways, first by using the program as the unit of analysis, and second by taking program participation numbers into consideration. Both strategies agree that interest in row crops, hay and fodder crops, and beef is high among both groups, and that interest in specialty crops is much higher among seekers than owners. When we take their participation numbers into consideration, the programs report seeing 230\% more seekers who wish to produce specialty crops than owners who presently do so. Other areas of substantially higher seeker interest than owner capacity include pastured hog/poultry production ( $84 \%$ more seekers), indoor hog/poultry production ( $74 \%$ more seekers), and dairy production (63\% more seekers).

\section{Assets to Transfer}

The questionnaire asked service providers to compare how common it is for owners and seekers to aim to transfer seven types of farm resources. These resources included (1) a farm business, (2) a home, (3) cropland, (4) pasture/range, (5) woods/ forest, (6) water (stream, pond, well), and (7) buildings, infrastructure, and/or facilities. All 21 programs that responded to this item reported differences between seekers and owners. Service providers observe differences across multiple types of resources (between two and seven types per program, with a mean of 4.2). Weighted values to reflect the magnitude of difference in their responses suggest that the largest difference is in housing. Service providers observe that many seekers are looking for on-farm housing, 2.8 times the number of owners who offer a farm home. The other highest priorities for seekers are cropland, infrastructure, a farm business, pasture or range, and water, in order of descending rank. In each of these categories, other than a business, the programs observe more than twice the need that participating owners make available.

\section{Phase 2: Online survey of farm seekers and farm owners}

\section{Description of Respondents}

A total of 516 responses represented 178 farm seekers and 338 farm owners. Median response times were three minutes for seekers and six minutes for owners, who received a longer set of questions. We subdivided farm owners according to their likelihood of transferring "some or all of your farm/ranch [land] one day to a non-relative (someone unrelated to you)." One subset includes those who are unlikely to transfer out of family $(n=155$, $47 \%$ ); the other includes those who are likely to transfer out of family, or neutral on the matter $(n=183,53 \%)$. We focus on the latter subset of owners to understand how seeker priorities align with those of owners more likely to transfer assets out of family. Among this subgroup of owners, $34 \%$ are extremely likely to transfer out of family, $31 \%$ are somewhat likely, and $35 \%$ are neutral. The locations of the seeker and owner respondents are depicted in Figure 1. Only 13\% of the respondents we analyze said they had actually participated in a farm link service; the other $87 \%$ subscribed to the mailing lists of the programs that distributed the survey, but are not active in their farm link services.

\section{Characteristics of Farm/Ranch Seekers}

Among seekers, the median age was 35 years. Many seeker respondents were women, who composed $38 \%$ of the group. Seekers were highly educated: $69 \%$ hold a bachelor's degree or higher. In terms of where these seekers are presently spending their work time, among $52 \%$ of seeker couples, neither person spends the majority of their work time farming. Among 23\% of seeker couples, one of the spouses is farming. Only $18 \%$ of seeker households presently earn half or more of their income from farming.

\section{Characteristics of the Subset of Farm/Ranch Owners} Farm/ranch owners represent owner-operators more than non-operators. Only $12 \%$ of the subset of owners were never the primary operators of their land. The other $88 \%$ are the primary operators or were at one time. The median owner age was 56 years and the majority of owner respondents were women $(52 \%)$. Owners are highly educated, with $77 \%$ holding a bachelor's degree and $44 \%$ holding a graduate degree. Again, only a minority of households earn most of their income from farming (31\%). Most owner households earn 
Figure 1. Map of Respondent Locations: Online Seeker/Owner Survey

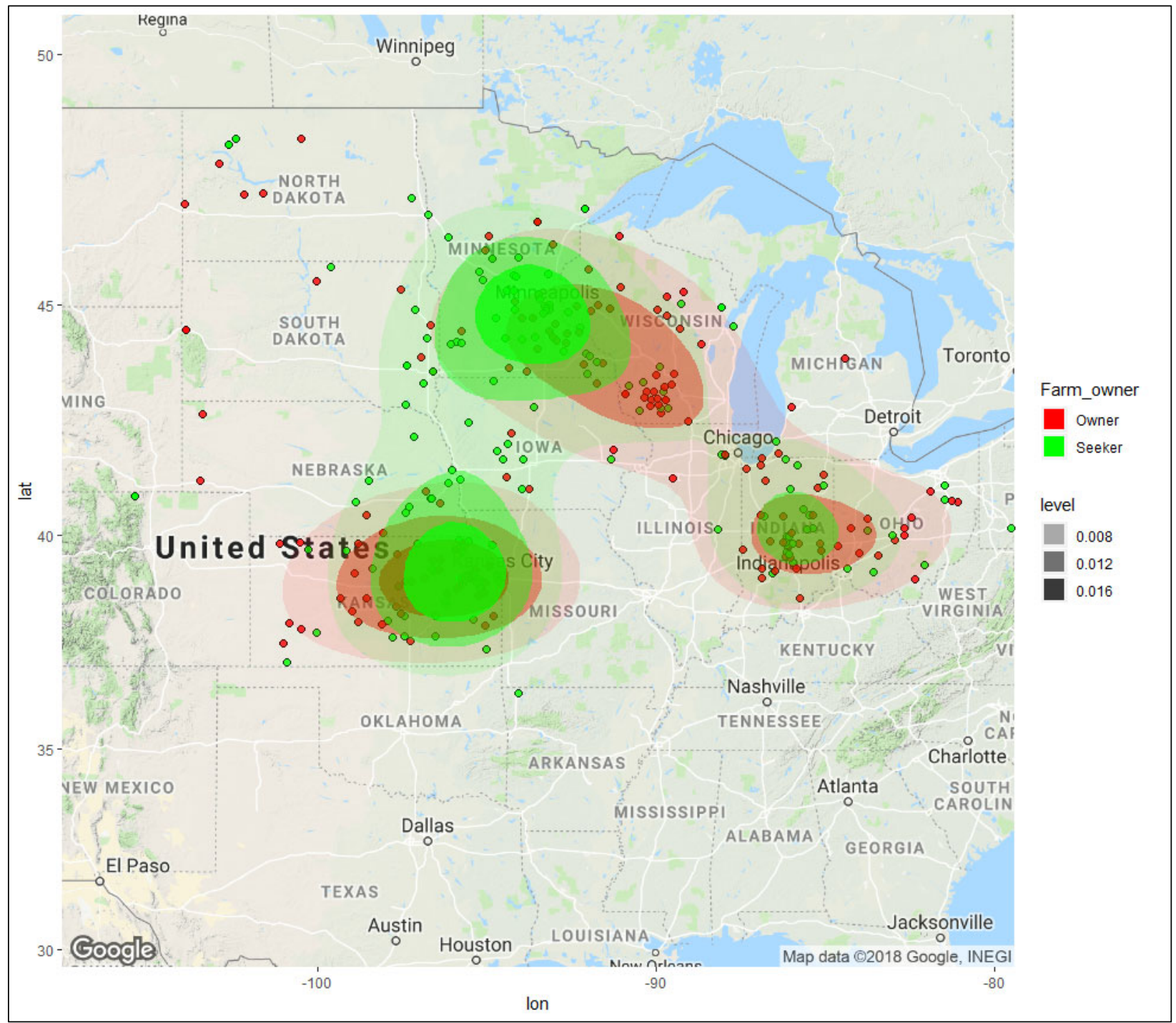

most of their income off the farm (69\%). Owner households are almost evenly divided as to whether someone spends the majority of their work time farming-no in the case of $48 \%$ of households. Table 2 shows the descriptive characteristics of the two respondent groups and the results of the Chisquared tests.

\section{Similarities between Seekers and the Subset of Owners}

Owner and seeker respondents to the online survey exhibit no statistical differences in the amounts of land they offer and seek ( $p=.222)$. Respondents selected one of eight options for acreage sought or offered, from less than 10 to more than 1,000.
While the owner and seeker median and most prevalent categories differ, response spread is distributed rather evenly across categories (owner median 40-80, seeker median 81-160). For higher acreages, seekers express greater demand for the largest tracts than owner respondents make available. Only $14 \%$ of owners offer land over 321 acres, while $23 \%$ of seekers are looking for this amount of land. Notably, in the smaller acreages, more owners proportionally are offering $11-80$ acres than seekers need.

In terms of location, these respondents demonstrate no statistically significant differences on a standard rural-urban continuum, neither when 
Table 2. Online Survey Responses: Seeker and Owner Characteristics and Results of Chi-Squared Tests

\begin{tabular}{|c|c|c|c|}
\hline Characteristic & $\begin{array}{l}\text { Owners neutral-to-likely to } \\
\text { transfer out of family }(n=183)\end{array}$ & $\begin{array}{l}\text { Seekers } \\
(n=178)\end{array}$ & $p$-value \\
\hline Rural-Urban binary (RUCA categorization C) & & & 0.187 \\
\hline Rural & $74(42.3 \%)$ & 59 (35.3\%) & \\
\hline Urban & $101(57.7 \%)$ & $108(64.7 \%)$ & \\
\hline Rural-Urban 4-level (RUCA categorization E) & & & 0.153 \\
\hline Isolated small rural town & $12(6.9 \%)$ & $4(2.4 \%)$ & \\
\hline Small rural town & $28(16.0 \%)$ & $21(12.6 \%)$ & \\
\hline Large rural city/town & $36(20.6 \%)$ & $34(20.4 \%)$ & \\
\hline Urban & $99(56.6 \%)$ & $108(64.7 \%)$ & \\
\hline House & & & 0.076 \\
\hline Any house & $145(88.4 \%)$ & $131(81.4 \%)$ & \\
\hline No house & 19 (11.6\%) & $30(18.6 \%)$ & \\
\hline \multicolumn{4}{|l|}{ Type of Housing } \\
\hline Primary only & $121(73.8 \%)$ & - & - \\
\hline Any Secondary house & $24(14.6 \%)$ & - & \\
\hline No residence & $19(11.6 \%)$ & - & \\
\hline Land available to transfer/sought & & & 0.222 \\
\hline 10 acres or fewer & $26(18.4 \%)$ & $29(17.7 \%)$ & \\
\hline $11-39$ acres & $36(25.5 \%)$ & $32(19.5 \%)$ & \\
\hline $40-80$ acres & $20(14.2 \%)$ & $16(9.8 \%)$ & \\
\hline $81-160$ acres & $22(15.6 \%)$ & $30(18.3 \%)$ & \\
\hline $161-320$ acres & $18(12.8 \%)$ & $19(11.6 \%)$ & \\
\hline $321-640$ acres & $11(7.8 \%)$ & $17(10.4 \%)$ & \\
\hline $641-1000$ acres & $2(1.4 \%)$ & $12(7.3 \%)$ & \\
\hline $1000+$ acres & $6(4.3 \%)$ & $9(5.5 \%)$ & \\
\hline Age group & & & $<0.001$ \\
\hline $18-29$ & $1(0.7 \%)$ & 39 (25.2\%) & \\
\hline $30-49$ & 49 (34.3\%) & 89 (57.4\%) & \\
\hline $50-69$ & $81(56.6 \%)$ & $26(16.8 \%)$ & \\
\hline $70-85$ & $12(8.4 \%)$ & $1(0.7 \%)$ & \\
\hline Gender & & & 0.014 \\
\hline Female & 79 (52.3\%) & $61(38.4 \%)$ & \\
\hline Male & $72(47.7 \%)$ & $98(61.6 \%)$ & \\
\hline Four-year degree & & & 0.083 \\
\hline Yes & $119(77.3 \%)$ & $109(68.6 \%)$ & \\
\hline No & $35(22.7 \%)$ & $50(31.4 \%)$ & \\
\hline Couple archetypes & & & $<0.001$ \\
\hline Both spouses farm & $23(14.4 \%)$ & $5(3.1 \%)$ & \\
\hline One spouse farms & $47(29.4 \%)$ & $37(22.7 \%)$ & \\
\hline Neither spouse farms & $54(33.8 \%)$ & $84(51.5 \%)$ & \\
\hline Single farmer & $13(8.1 \%)$ & $10(6.1 \%)$ & \\
\hline Single non-farmer & $23(14.4 \%)$ & $27(16.6 \%)$ & \\
\hline \multicolumn{3}{|c|}{ Household earns half or more of income from farming, ranching, or livestock production } & 0.007 \\
\hline Yes & $47(30.7 \%)$ & $28(17.7 \%)$ & \\
\hline No & $106(69.3 \%)$ & $130(82.3 \%)$ & \\
\hline \multicolumn{3}{|c|}{ Off-farm household income received in 2016 (US\$) } & 0.006 \\
\hline$\$ 0-29,999$ & $52(36.1 \%)$ & $39(24.8 \%)$ & \\
\hline$\$ 30,000-79,999$ & $48(33.3 \%)$ & $77(49.0 \%)$ & \\
\hline$\$ 80,000-149,999$ & $29(20.1 \%)$ & $35(22.3 \%)$ & \\
\hline$\$ 150,000+$ & $15(10.4 \%)$ & $6(3.8 \%)$ & \\
\hline
\end{tabular}


using a four-level categorization $(\phi=.153)$ nor with a two-level rural-urban dichotomy ( $p=.187)$.

\section{Notable Differences between Seekers and the Subset of Owners}

Housing is an area of divergence. Most seekers $(81 \%)$ are looking for a farm that comes with housing. However, among owners, $74 \%$ have only their primary residence on the farm, and $12 \%$ of owners have no residence at all on their farm. Only $15 \%$ of owners have a secondary residence on their property. Although our tests were not able to further explore any disconnect between seekers desiring affordable on-farm housing and whether owners may prefer on-farm housing in retirement, it is one discord in the puzzle of farm transfers that we explore in the discussion.

In terms of gender, more than half of owner respondents were women $(52 \%)$. Seeker respondents were $62 \%$ male, and therefore statistically more likely than owners to be men ( $p=.014)$.

Farming factors into household livelihoods differently for these owners and seekers, to a statistically significant extent. Owner households are more likely than seeker households to have someone spending most of their work time farming $(52 \%$ of owner households versus $32 \%$ of seeker households). In terms of levels of off-farm income, owners are more likely to report the lowest and highest income categories (less than US\$30,000 and US $\$ 150,000+$ ), whereas seekers are more prevalent in the middle categories (US $\$ 30,000-$ US $\$ 79,999$ and US $\$ 80,000-U S \$ 149,999), p=.006$.

\section{Discussion}

In exploring compatibilities between farm seekers and farm owners whose assets may transfer out of family, the data suggest some congruencies, some barriers, and some clear areas for continuing investment and research. The strongest area of agreement in this study is on the role of the farm home as a potentially severe obstacle to farm transference. A large majority of seekers desire an onfarm residence, but few owners offer on-farm residences. Findings diverge around the farmland tract sizes sought by seekers and offered by owners, which we explore below. The expectation was tested that desiring locations closer to urban cen- ters would predominate among seekers, and found seeker and owner geographic locations to be comparable. Turning to owners' products and seekers' desired agricultural products, we explore below how seeker demand matches owner capacity for some product areas and far surpasses it for others. An expected dissimilarity is that service providers would report high interest in specialty crop production among seekers.

\section{Unexpected Similarity: Seeker and Owner Locations are Compatible on a Rural-Urban Continum}

This analysis finds no statistically significant difference between seeker and owner survey respondents' locations on a rural-to-urban continuum. Thus, one expected barrier between them was not present according to the mechanism used here, the zip code approximation for USDA ERS-RUCA values. RUCA measures the commuting patterns of a place in order to indicate its relation to neighboring employment centers (National Academies of Sciences, Engineering, and Medicine, 2016). Useful follow-up analyses will nevertheless continue to examine seeker and owner locations according to other county and zip code indicators, as well as at more granular levels, to further consider how geography factors into prospective matches for farm transfers. For example, some analyses have looked specifically at how prospects for agricultural entrepreneurship and farm transfer are evolving at the edges of cities, where food system networks are potentially most dense, but where competition for land uses raises land prices (Carolan, 2018; Clark, Inwood, \& Sharp, 2012; Lange, Piorr, Siebert, \& Zasada, 2013). Farms located at this rural-urban interface face a distinctive set of opportunities and challenges in persisting in agriculture and transferring to a new farmer.

\section{Mixed Findings: Acreages and Agricultural Products Comparing amounts and sizes of land parcels sought and offered, the seeker/owner survey demonstrated no differences between groups, suggesting a potential fit for attempts to match seekers and owners. Similarly, managers of half the programs in the assessment observed no differ- ences in the land parcels sought and offered by their seeker and owner participants.}


Differences, however, are sizeable among the half of programs that did report seekers needing different land parcels, and more land in total, than owners have to offer. Factoring in program participation numbers, the programs that reported differences present the greatest discordance in the 500-999 acre range. They observed 100 times the demand for 500-999 acreages from seekers than what is available. These respondent programs are located in the western part of the region and share a focus on preparing commodity feed grain producers and linking them to resources. A greater number of programs agreed that seeker demand for the smallest tracts (under 40 acres) is six to seven times what is available. Since these are the land sizes most wanted by seekers, future research and investment could prioritize owners of tracts of these sizes for potential linking and transfer initiatives.

Service providers reported as to how owner participants' agricultural products compare with what seekers aim to produce. The managers' observations indicate high interest among seekers in growing specialty crops, at a level that greatly surpasses owners' experience. Service providers also indicated high interest among seekers in products that see equally high experience among owners: row crops, hay/fodder crops, and beef. It bears noting that this pattern of high participation in farm link programs by commodity broadacre farmers is likely specific to certain distinctive programs of the region. A few of the NCR states invest much more than the rest of the country in linking farm owners to seekers by providing comprehensive farm matching services and beginning farmer tax credits (Hamilton, 2010; Meuleners, 2013; Slack, 2013; Valliant \& Freedgood, in press; Williamson \& Girardi, 2016). These mechanisms and services attract the participation of hundreds to thousands of farm owners per year, most of them commodity feed grain producers (Beck, Carter \& Circo, 2018; Girardi, 2015). These are longstanding formal attempts to connect farm seekers to land access (Valliant et al., 2019), some of which provide a financial incentive to owners who choose a qualifying beginning farmer as their farm's next operator or owner. Since these are much higher owner participation numbers than what is seen by any other type of initiative, in the region or nationally, these programs may provide exceptional insight into patterns of high demand for, and supply of, some types of commodity production resources.

Fewer seekers wish to produce dairy, hogs, or poultry (whether indoors or outdoors), although, again, programs observed much more interest in these products among seekers than owners with experience in these areas. These patterns vary somewhat according to whether the unit of analysis is the individual program or the number of participants in a program. Incorporating participation numbers into the analysis shifts patterns toward the results involving programs whose participation numbers are higher. In general, these are programs that primarily serve commodity growers, but nevertheless, the entire group of programs reported three times the number of entering specialty crop farmers than the number of outgoing. The consistent pattern across analytical approaches is that interest in specialty crop production among seekers is far greater than what owners offer. The product areas of specialty crops, hogs, poultry, and dairy, therefore, demand continued and even greater focused support from program initiatives, while row crop, beef, and hay/fodder infrastructure appear to be well-matched with incoming demand to produce these commodities.

\section{Notable Barrier: Housing}

Housing is the area of least alignment between farm owners and farm seekers. Among owner and seeker respondents, the majority of owner farms only have one dwelling, and $12 \%$ of owner farms have no dwelling. Only 15\% of owners have a secondary house on their property. In contrast, $81 \%$ of seekers are looking for a house. Service providers also observe an imbalance. When we consider program participation numbers, farm housing surfaces as the most prevalent need that seekers have, such that the demand for housing is nearly three times higher than what is offered by owners. We did not test, but do assume, that owners prefer to continue living at the farm in retirement (Gill, 2008; Leonard, S. H., \& Gutmann, 2006). Some research suggests, however, that this desire may be felt more strongly by farm 
men than farm women (Downey, Threlkeld, \& Warburton, 2017; Riley, 2012).

Given that the farm is the family home (Katchova \& Ahearn, 2016) and that "movement away from the farm... [is] an often inconceivable act" for older farmers (Riley, 2016, p. 110), then where will an entering farm family reside? This is a tension in the transfer formula that the literature often states is central (Hersey \& Adams, 2017; Lobley et al., 2010; Riley, 2016; Ruhf, 2013), but then generally stops short of analyzing the gap. Our findings spotlight the need for much more research and policy innovation to support adequate options for incoming farmers who wish to reside on the farm. Recent assessments describe the extent to which accessing on-farm housing is part of the difficulty of land access. When the National Young Farmers Coalition surveyed current, former, and aspiring farmers under 40 years of age $(N=3,517)$, access to affordable housing ranked in the top five most common challenges (Ackoff et al., 2017). This pattern represented obstacles from the perspective of each subgroup, including reasons that past farmers stopped farming and that aspiring farmers are not yet farming. American Farmland Trust also found housing to be part of "the most conspicuous gap" faced by beginning farmers (Freedgood \& Dempsey, 2014, p. 1).

These and other reports suggest points for advocacy in federal, state, and local policies (Ackoff et al., 2017). Calls for state action include incorporating housing considerations into farmland preservation initiatives and replicating and expanding existing incentives for farm owners to build and improve farm laborer housing (Parsons et al., 2010). State and county zoning conventions are another focus (Brandt-Sargent, 2010) because their well-intentioned efforts to prevent agricultural land from fractionating for residential development can restrict housing from being built on lots smaller than a certain acreage (20 or even 80 acres, for example) in agricultural areas (Horst \& Gwin, 2018). Specific policy recommendations should aim to make existing on-farm housing more accessible and affordable for incoming farmers. At the federal level, analyses support the effort of USDA Rural Development programs to reinforce rural housing, such as through the Rural Housing Service and expansion of the Community Facilities Direct Loan and Grant Program to include purchases of onfarm housing infrastructure (Calo \& PetersenRockney, 2018). Innovations at the local level include deed riders to link residential and agricultural parcels to ensure affordable housing adjacent to agricultural activities (Parsons et al., 2010). These advocacy specifics fall under a wider call for rural development policies that are dedicated to more effectively and holistically consider agricultural livelihoods, market infrastructure, and the place of farm transfer in rural community creation going forward (Inwood, 2013).

\section{Limitations}

This analysis highlights a segment of entering farmers who are seeking non-family land. New farmers with other prospects for accessing land do not show up here, so we do not generalize beyond this subpopulation. Topically, this analysis leaves out the financial and relational factors that play a large role in any farm transfer and instead focuses on the parties' structural priorities. We did this by surveying farm/ranch owners who expect to transfer out of family and farm seekers, as well as experts whose work caters to these two parties. The survey of seekers and owners reflects an availability, or convenience, sample of respondents whose motivations led them to respond to this online survey. We are unable to compare these seekers and owners to nonrespondents. A specific limitation relative to our finding on seeker and owner geographical locations is that while we asked respondents to provide a zip code, we failed to direct owners to provide a zip code for their farm specifically. Farm owners may have reported their residential zip code or post office box. Specific to the section on housing, we did not ask owners about the possibility of new construction on their farms.

\section{Conclusions and Recommendations}

One goal of farm link services is to foster intergenerational farm transfers as an opportunity for incoming farmers to transfer into a farm that has no family member to take it over. We examine a criticism of farm link services (Fraas, 2015; Hersey $\&$ Adams, 2017) that they are based on an erroneous assumption that potential matches exist be- 
tween incoming and outgoing farmers based on similar structural needs and offers. Our findings offer a nuanced view of this criticism through a focus on farm link services, farm seekers, and farm owners likely to transfer out of family in the U.S. North Central Region. Table 3 summarizes the findings. We find seekers and owners to be compatible in their locations on a rural-urban spectrum. Turning to land parcel sizes, both research phases agree that the 40-99 acre range is particularly where owners and seekers are well-matched, as supply and demand are both high in this range. However, in the less-than-40-acre-parcel range, service providers report that seeker demand is much higher than owners' offers. They also observe that, in the larger acreages, incoming commodity farmers need more 500-999 acre tracts than owners make available.

To explore these supply and demand dynamics relative to farm scale, we incorporate a focus on product mix. Service providers report that the number of aspiring commodity row crop, beef, and hay/fodder crop farmers aligns well with the number of commodity broadacre farms offered. On the other hand, owners appear to offer many fewer resources than what is needed to meet seeker ambitions to produce specialty crops, dairy, and hogs/poultry (outdoor and indoor). Therefore, our recommendations cast light on these latter sectors and smaller scales of agriculture. Our findings indicate that priority for research and policy and programmatic innovation, especially in this region, needs to be placed on unlocking opportunities for owners of parcels under 100 acres, and especially under 40 acres, to transfer to incoming seekers. Dedicating additional farm transfer support to existing specialty crop, dairy, and hog/poultry operations would also be well justified. As an example, the Dairy Grazing Apprenticeship provides one such model (Franzluebbers et al., 2012; Valliant et al., 2019) because it provides a two-year training program through which new grazing-based dairy farmers prepare to lead existing dairies, with master graziers serving as mentors. It creates a mechanism for transferring established dairy operations into the future.

Last, our most salient finding is that a top need for all aspiring farmers, regardless of the agricultural sector, is an affordable on-farm residence. We urge both research practitioners and interventionist

Table 3. Summary of Findings by Study Phase, Analytical Approach, and Area of Comparison

\begin{tabular}{|c|c|c|c|}
\hline \multirow[b]{2}{*}{ Area of Comparison } & \multicolumn{2}{|c|}{ Phase 1: Program Assessment } & \multirow{2}{*}{$\begin{array}{c}\text { Phase 2: Seeker/Owner } \\
\text { Survey }\end{array}$} \\
\hline & Programs & Participation Numbers & \\
\hline Home & $\begin{array}{l}\text { Seeker interest in transferring } \\
\text { a home is greater than } \\
\text { owners' }\end{array}$ & $\begin{array}{l}\text { A home is the top-ranked } \\
\text { need of seekers. Seekers' } \\
\text { need for a home is three } \\
\text { times greater than what } \\
\text { owners are offering. }\end{array}$ & $\begin{array}{l}81 \% \text { of seekers need a home, } \\
\text { but only } 15 \% \text { of owners have a } \\
\text { secondary home on their farm }\end{array}$ \\
\hline Acreage & \multicolumn{2}{|c|}{$\begin{array}{l}\text { - Seekers' demand for parcels less than } 40 \text { acres is higher } \\
\text { than owners' supply } \\
\text { - } 40-99 \text { acre parcels are highly sought and demanded; here, } \\
\text { seekers and owners are closely matched } \\
\text { - Beginning commodity producers need larger tracts than } \\
\text { owners offer }\end{array}$} & $\begin{array}{l}\text { No statistically significant } \\
\text { differences across parcels } \\
\text { sought by seekers and offered } \\
\text { by owners }\end{array}$ \\
\hline Rural/urban location & \multicolumn{2}{|l|}{ N/A } & $\begin{array}{l}\text { No differences between } \\
\text { seeker and owner locations }\end{array}$ \\
\hline Product alignment & \multicolumn{2}{|c|}{$\begin{array}{l}\text { - Seeker interest in growing specialty crops is high, much } \\
\text { higher than owner experience } \\
\text { - Seeker interest is also high in row crop, hay/fodder, and } \\
\text { beef production, at a level that matches owner experience } \\
\text { - Fewer seekers are interested in dairy and hog/poultry } \\
\text { production (indoor or outdoor), but interest is still higher } \\
\text { than owner experience }\end{array}$} & $\mathrm{N} / \mathrm{A}$ \\
\hline
\end{tabular}


stakeholders to dedicate attention to supporting new farmers' transitions with a stock of affordable on-farm housing, as a central component of farmland access. Policy, programmatic, and research recommendations are presented in the above discussion of housing. These inquiries will need to examine how housing access aligns with policy strategies to preserve farmland and agricultural landscapes. Rural on-farm housing deserves particular consideration in the effort to cycle new generations into agriculture.

\section{Acknowledgments}

The authors wish to acknowledge the leaders of programs who participated in this assessment for generously sharing their experience and insight. A team of national advisors helped to guide this research; particular thanks are extended to Mary Fund, Wyatt Fraas, Kevin Gibson, and Maria Marshall. Many thanks as well go to Dave Welsch, J. R. Brooks, and Sage Danch for reviewing the data collection instruments in draft form.

\section{References}

Ackoff, S., Bahrenburg, A., \& Shute, L. L. (2017). Building a future with farmers II: Results and recommendations from the national young farmer survey. Hudson, NY: National Young Farmers Coalition. Retrieved from https://www.youngfarmers.org/wp-content/uploads/2018/02/NYFC-Report-2017.pdf

Ahearn, M. C. (2013). Beginning farmers and ranchers at a glance. Washington, DC: U. S. Department of Agriculture, Economic Research Service. Retrieved from https://www.usda.gov/media/blog/2013/01/30/beginning-farmers-and-ranchers-glance

Beck, C., Carter, M., \& Circo, A. (2018). The Beginning Farmer Tax Credit Act: Performance on selected metrics. Lincoln, NE: State Capitol, Legislative Performance Audit Committee. Retrieved from https://nebraskalegislature.gov/pdf/reports/audit/begfarm 2018.pdf

Brandt-Sargent, B. (2010). Accessory dwelling units to support farm transitions. Minnesota: Renewing the Countryside \& Center for Urban and Regional Affairs. Retrieved from http://d3n8a8pro7vhmx.cloudfront.net/renewingthecountryside/pages/129/attachments/original/1401393367/R TC ADUs to support farm transitions.pdf?1401393367

Calo, A., \& Petersen-Rockney, M. (2018). What beginning farmers need most in the next farm bill: Land (Policy brief). Berkeley: University of California, Berkeley, Berkeley Food Institute. Retrieved from https://food.berkeley.edu/wp-content/uploads/2018/08/BFI-Beginning-Farmers-Policy-Brief.pdf

Carolan, M. (2018). Land changing hands: Experiences of succession and farm (knowledge) acquisition among firstgeneration, multigenerational, and aspiring farmers. Land Use Policy, 79, 179-189. https://doi.org/10.1016/j.landusepol.2018.08.011

Chiswell, H. M. (2014). The importance of next generation farmers: A conceptal framework to bring the potential successor into focus. Geography Compass, 8(5), 300-312. https://doi.org/10.1111/gec3.12131

Clark, J. K., Inwood, S., \& Sharp, J. S. (2012). Local food systems: The birth of new farmers and the demise of the family farm? In J. D. Gatrell, P. S. Ross, \& N. Reid (Eds.), Local food systems in old industrial regions: Concepts, spatial context, and local practices (pp. 131-146). Abingdon, Oxon, UK: Routledge.

Downey, H., Threlkeld, G., \& Warburton, J. (2017). What is the role of place identity in older farming couples' retirement considerations? Journal of Rural Studies, 50, 1-11. https://doi.org/10.1016/i.jrurstud.2016.12.006

Farmer, J. R., \& Valliant, J. C. D. (2016). Transitioning farm and ranch land from one family to another: Evaluating new strategies for profitable transfers and sustainable agriculture partnerships [Project report]. College Park, MD: USDA National Institute of Food and Agriculture (NIFA) Sustainable Agriculture Research \& Education (SARE). Retrieved from https://projects.sare.org/sare project/lnc16-377/

Fraas, W. (2015). Land access support for beginning farmers and ranchers: Center for Rural Affairs Strategy \& Services. Lyons, NE: Center for Rural Affairs.

Franzluebbers, A. J., Paine, L. K., Winsten, J. R., Krome, M., Sanderson, M. A., Ogles, K., \& Thompson, D. (2012). Well-managed grazing systems: A forgotten hero of conservation. Journal of Soil and Water Conservation, 67(4), 100A-104A. https://doi.org/10.2489/jswc.67.4.100A 
Freedgood, J., \& Dempsey, J. (2014). Cultivating the next generation: Resources and policies to belp beginning farmers succeed in agriculture. Washington, D.C.: American Farmland Trust. Retrieved from https://4aa2dc132bb150caf1aa7bb737f4349b47aa42dce777a72d5264.ssl.cf5.rackcdn.com/AFT BF 06-2014-lo.pdf

Gill, F. (2008). Moving to the 'big' house: Power and accommodation in inter-generational farming families. Rural Society, 18(2), 83-94. https://doi.org/10.5172/rsj.351.18.2.83

Girardi, A. G. (2015). Beginning Farmer Tax Credit Program: Tax credit program evaluation study. Des Moines: Iowa Department of Revenue.

Grubbström, A., \& Eriksson, C. (2018). Retired farmers and new land users: How relations to land and people influence farmers' land transfer decisions. Sociologia Ruralis, 58(4), 707-725. https://doi.org/10.1111/soru.12209

Hamilton, N. D. (2010). America's new agrarians: Policy opportunities and legal innovations to support new farmers. Fordham Environmental Law Review, 22(3), 523-562. Retrieved from https://www.vabeginningfarmer.alce.vt.edu/content/dam/vabeginningfarmer alce vt edu/resources/AMERICA SNEWAGRARIANS.pdf

Harper, D. (2015). Partnering with next-generation farmers. Washington, D.C.: Land Trust Alliance. Retrieved from https://www.landtrustalliance.org/news/partnering-next-generation-farmers

Hersey, A., \& Adams, M. (2017). Using contribution analysis to assess the influence of farm link programs in the U.S. Journal of Agriculture, Food Systems, and Community Development, 7(3), 83-103. https://doi.org/10.5304/jafscd.2017.073.006

Horst, M., \& Gwin, L. (2018). Land access for direct market food farmers in Oregon, USA. Land Use Policy, 75, $594-611$. https://doi.org/10.1016/j.landusepol.2018.01.018

Ingram, J., \& Kirwan, J. (2011). Matching new entrants and retiring farmers through joint farm ventures: Insights from the Fresh Start Initiative in Cornwall, UK. Land Use Policy, 28(4), 917-927. https://doi.org/10.1016/i.landusepol.2011.04.001

Inwood, S. M. (2013). Social forces and cultural factors influencing farm transition. Choices, 28(2), 1-5. Retrieved from http://www.choicesmagazine.org/UserFiles/file/cmsarticle 309.pdf

Inwood, S. M., \& Sharp, J. S. (2012). Farm persistence and adaptation at the rural-urban interface: Succession and farm adjustment. Journal of Rural Studies, 28(1), 107-117. https://doi.org/10.1016/j.jrurstud.2011.07.005

Katchova, A. L., \& Ahearn, M. C. (2016). Dynamics of farmland ownership and leasing: Implications for young and beginning farmers. Applied Economic Perspectives and Policy, 38(2), 334-350. https://doi.org/10.1093/aepp/ppv024

Katchova, A. L., \& Ahearn, M. C. (2017). Farm entry and exit from US agriculture. Agricultural Finance Review, 77(1), 50-63. https://doi.org/10.1108/AFR-03-2016-0021

Lange, A., Piorr, A., Siebert, R., \& Zasada, I. (2013). Spatial differentiation of farm diversification: How rural attractiveness and vicinity to cities determine farm households' response to the CAP. Land Use Policy, 31, $136-144$. https://doi.org/10.1016/j.landusepol.2012.02.010

Leonard, B., Kinsella, A., O’Donoghue, C., Farrell, M., \& Mahon, M. (2017). Policy drivers of farm succession and inheritance. Land Use Policy, 61, 147-159. https://doi.org/10.1016/j.landusepol.2016.09.006

Leonard, S. H., \& Gutmann, M. P. (2006). Land use and transfer plans in the U. S. Great Plains. Great Plains Research, 16, 181-193. Retrieved from https://www.unl.edu/plains/publications/GPR/gpr.shtml

Lobley, M., \& Baker, J. R. (2012). Succession and retirement in family farm businesses. In M. Lobley, J. R. Baker, \& I. Whitehead (Eds.), Keeping it in the family: International perspectives on succession and retirement on family farms (pp. 1-20). Farnham, Surrey, UK: Ashgate.

Lobley, M., Baker, J. R., \& Whitehead, I. (2010). Farm succession and retirement: Some international comparisons. Journal of Agriculture, Food Systems, and Community Development, 1(1), 49-64. https://doi.org/10.5304/jafscd.2010.011.009

Meuleners, A. (2013). Finding fields: Opportunities to facilitate and incentivize the transfer of agricultural property to new and beginning farmers. Drake Journal of Agricultural Law, 18(1), 211-238. Retrieved from http://aglawjournal.wp.drake.edu/wp-content/uploads/sites/66/2016/09/agVol18No1-Meuleners.pdf 
National Academies of Sciences, Engineering, and Medicine. (2016). Rationalizing rural area classifications for the Economic Research Service: A workshop summary. Washington, D.C.: The National Academies Press. https://doi.org/10.17226/21843

Paine, L., \& Sullivan, A. (2014). Beginning Farmers in Wisconsin: 2014 Survey Summary. Madison: Wisconsin Department of Agriculture.

Parsons, R., Ruhf, K. Z., Stevenson, G. W., Baker, J., Bell, M., Epley, E., . . Keller, J. (2010). Research report and recommendations from the FarmLASTS Project. Washington, D.C.: USDA, National Institute of Food and Agriculture. Retrieved from http://www.uvm.edu/farmlasts/FarmLASTSResearchReport.pdf

Patton, M. Q. (2002). Qualitative research \& evaluation methods (3 $3^{\text {rd }}$ ed.). Thousand Oaks, CA: Sage.

Riley, M. (2012). 'Moving on'? Exploring the geographies of retirement adjustment amongst farming couples. Social \& Cultural Geography, 13(7), 759-781. https://doi.org/10.1080/14649365.2012.725136

Riley, M. (2016). Still being the 'good farmer': (Non-)retirement and the preservation of farming identities in older age. Sociologia Ruralis, 56(1), 96-115. https://doi.org/10.1111/soru.12063

Ruhf, K. Z. (2013). Access to farmland: A systems change perspective. Journal of Agriculture, Food Systems, and Community Development, 4(1), 51-60. https://doi.org/10.5304/jafscd.2013.041.006

Schilling, B. J., Esseks, J. D., Duke, J. M., Gottlieb, P. D., \& Lynch, L. (2015). The future of preserved farmland: Ownership succession in three Mid-Atlantic states. Journal of Agriculture, Food Systems, and Community Development, 5(2), 129-153. https://doi.org/10.5304/jafscd.2015.052.008

Schutt, R. K. (2006). Investigating the social world (5th ed.). Thousand Oaks, CA: Sage.

Slack, T. (2013). Challenges facing elder farmers and the need for a nationwide Farm-On program. Elder Law Journal, 20(2), 485-520. Retrieved from https:/ theelderlawjournal.com/archives/

U.S. Department of Agriculture, Economic Research Service [USDA ERS]. (2016). Rural-urban commuting area codes. Washington, D.C.: USDA ERS. Retrieved from https://www.ers.usda.gov/data-products/rural-urban-commuting-area-codes/

USDA ERS. (2017). Cash receipts by commodity state ranking. Washington, D.C.: USDA ERS. Retrieved from https://data.ers.usda.gov/reports.aspx?ID=17844

USDA ERS. (2019). Beginning, limited resource, socially disadvantaged and female farmers. Washington, D.C.: USDA ERS. Retrieved from https://www.ers.usda.gov/topics/farm-economy/beginning-limited-resource-socially-disadvantaged-and-female$\underline{\text { farmers/ }}$

USDA National Agricultural Statistics Service [USDA NASS]. (2012a). Table 8. Farms, land in farms, value of land and buildings, and land use: 2012 and 2007. Washington, D.C.: USDA NASS, Census of Agriculture. Retrieved from https://www.agcensus.usda.gov/Publications/2012/Full Report/Volume 1, Chapter 2 US State Level/st99 2 008_008.pdf

USDA NASS. (2012b). Table 55. Selected operator characteristics for principal, second, and third operator: 2012. Washington, D.C.: USDA NASS, Census of Agriculture. Retrieved from https://www.nass.usda.gov/Publications/AgCensus/2012/Full Report/Volume 1, Chapter 1 US/st99 10550 $\underline{55 . p d f}$

USDA NASS. (2014). Beginning farmers_Characteristics of farmers by years on current farm (ACH12-5). Washington, D.C.: USDA NASS. Retrieved from https://www.nass.usda.gov/Publications/Highlights/2014/Beginning Farmers/index.php

USDA NASS. (2015). Farmland ownership and tenure. Washington, D.C.: USDA NASS. Retrieved from https://www.nass.usda.gov/Publications/Highlights/2015/TOTAL Highlights.pdf

USDA NASS. (2016). 2016 Agricultural Resource Management Survey, costs and returns report_Version 1. Washington, D.C.: USDA NASS. Retrieved from https://www.nass.usda.gov/Surveys/Guide to NASS Surveys/Ag Resource Management/ 
USDA, National Institute of Food and Agriculture, Sustainable Agriculture Research \& Education [USDA NIFA SARE]. (2018). SARE projects database. College Park, MD: USDA NIFA SARE. Retrieved from https://projects.sare.org/search-projects/

University of North Dakota Center for Rural Health. (2014). Temporary zip RUCA 3.10 file access page. Grand Forks: UND Center for Rural Health. Retrieved from https://ruralhealth.und.edu/ruca

University of Washington Rural Health Research Center. (2005). RUCA data: Using RUCA data. Seattle, WA: WWAMI Rural Health Research Center. Retrieved from http://depts.washington.edu/uwruca/ruca-uses.php

Valliant, J. C. D., \& Freedgood, J. (in press). Land access policy incentives: Emerging approaches to transitioning farmland to a new generation. Journal of Agriculture, Food Systems, and Community Development.

Valliant, J. C. D., Ruhf, K. Z., Gibson, K. D., Brooks, J. R., \& Farmer, J. R. (2019). Fostering farm transfers from farm owners to unrelated, new farmers: A qualitative assessment of farm link services. Land Use Policy, 86, 438-447. https://doi.org/10.1016/j.landusepol.2019.05.004

Williamson, J. M., \& Girardi, A. (2016, May). Income tax credits to assist beginning farmers and ranchers: A look at state-level policies. Paper presented at the annual meeting of the Agricultural and Applied Economics Association, Boston, MA. Retrieved from https://ageconsearch.umn.edu/record/235810/files/Williamson AAEA $\% 202016 \% 20 \mathrm{BFTC} \% 20 \mathrm{manuscript}$ \%20FINAL.pdf 